\title{
Application of PAKEM Approach Assisted Beads to Increase Interest and Learning Achievement of Fourth Grade Students
}

\author{
Yuyun Dwi Haryanti \\ Majalengka University, Indonesia \\ yuyundwiharyanti18@gmail.com
}

\begin{abstract}
Factors causing the low interest and achievement of fourth grade students of Elementary School 1 Wanadadi, Banjarnegara in learning Mathematical concepts of counting operations summing integers that the learning process is still running one-way, the way teachers teach boring, props used less interesting, lesson material to equip students. This study aims to improve the learning process so that students have high interest and learning achievement. This Classroom Action Research is conducted in 3 cycles through a cycle study consisting of 4 stages: planning, execution, observation and reflection. The result of the research showed that the students 'achievement and the students' interest increased with the following details: Initial study of the students completed in the study only 7 students (23\%) of 31 students, on the first cycle students complete 10 students (32\%), Completed 19 students (61\%), cycle III students who completed 26 students or $85 \%$. Student learning interest also increased from cycle I only $45 \%$ of students who have high learning interest, cycle II increased to $65 \%$ and in the third cycle increased to $95 \%$. The conclusion can be drawn that the application of PAKEM approach with beads aids to make students have high learning interest and help facilitate students' understanding so as to have an impact on student achievement.
\end{abstract}

Keywords: PAKEM approach, beads, interest to learn, learning achievements

\section{INTRODUCTION}

Mathematics as a very important lesson in everyday life. Various sciences such as language, science and social studies have something to do with mathematics. Mathematics as a universal science underlies the development of technology and has an important role in various disciplines. Rapid development in the coverage of technology and communication today is based on the development of mathematics in the field of number theory, algebra, analysis, probability theory and discrete Mathematics. A person can dominate and create in the future required mastery of Mathematics from an early age. This is in line with Government Regulation No. 19 of 2005 article 6 , paragraph 6 states that the ability to count as one of the skills that need to be emphasized in elementary school students.

Mathematics is the process of providing learning experiences to learners through a series of planned activities so that learners acquire competence on Mathematics materials studied. One component that determines competence achievement is the use of mathematics learning strategies that are appropriate to: (1) topics being discussed; (2) the level of intellectual development of learners; (3) learning principles and theories; (4) active involvement of learners; 5) relevance to the lives of everyday learners; and (6) the development and understanding of mathematical reasoning (Muhsetyo, 2008).

Learning Mathematics in Primary School so that he is able to equip his students with meaningful learning so that students become smart in mathematics. Mathematics lessons for elementary school students many assume as a difficult subject, boring and also some who commented disgusted when hearing the word Math. Seeing this, as a professional teacher will not find silent will certainly find a bridge to solve such problems.

On the based of observations at Elementary School 1 Wanadadi during the learning process of mathematics teachers using a lecture model where students listen to the explanation of teachers and students are given the task to do the questions given by the teacher. The process of learning Mathematics has never used visuals because of the limitations of school facilities. This affects the low interest and achievement of students in learning mathematics, especially in the fourth class concept of count arithmetic summing integers can be seen from the value of daily repetition results. Of the 31 students only 7 students (23\%) who scored above KKM (Criterion of Minimum Completion) is 80 (eighty).

Based the identification of the above problems, it is suspected that the root causes of the problems are as follows: (1) the learning process goes one way, the passive students and the teacher use the caramah method more; (2) the way teachers teach boring and strategies in monotonous learning; (3) the props used are less attractive so as not to foster students' interest in learning; (4) learning materials do not equip students to apply learning materials in everyday life. Based on the above description of the researcher trying to solve problems such as what becomes a teacher's troubles with Applying PAKEM Approach Behavioral Assistance in Mathematics Learning to Increase Interest and Achievement of Class IV Students.

\section{METHODS}

This research was conducted in Elementary School one Wanadadi subdistrict Wanadadi, district Banjarnegara with the target of fourth graders of the year 2015/ 2016. Research subjects as many as 31 students with the number of male students as many as 18 children and female students amounted to 13 students. The research methods used include Classroom Action Research (PTK). Classroom Action Research is a reflective study carried out in a cycle. Classroom action research consists of a series of four activities performed in a recurring cycle. The four main activities that exist in each cycle are planning of action, acting, observing, and reflecting. 


\section{RESULT AND DISCUSSION}

The research is done through three cycles each cycle is done with the duration of the learning process ( $2 \times 35$ minutes). At the beginning of the study of students' interest in the subject of Mathematics is still low so that the impact on student achievement where only $23 \%$ of students who reach the Minimum Exhaustiveness Criteria is 80 while $77 \%$ student achievement is still below KKM. These conditions create anxiety for the teacher so that the need for problem solving through improvement of learning in the classroom.

Cycle I

In the first cycle is done through four stages of planning, implementation, observation, and reflection. At the planning stage the researcher prepares with the learning tools to be used in the research. The learning tool that prepares the researcher is as follows: (1) preparing the learning scenario; (2) preparing the beads; (3) preparing the Student Worksheet; (4) preparing the data collection instrument; and (5) coordinating with the observer. In the first cycle is done through four stages of planning, implementation, observation, and reflection. At the planning stage the researcher prepares with the learning tools to be used in the research. The learning tool that prepares the researcher is as follows: (1) preparing the learning scenario; (2) preparing the beads; (3) preparing the Student Worksheet; (4) preparing the data collection instrument; and (5) coordinating with the observer.

Implementation phase of the researcher undertakes the learning action as planned in the planning stage ie the use of beads with PAKEM approach on learning the concept of count arithmet for the addition of positive and negative integers. Improvement actions are detailed in the form of steps of teacher-student activities through initial activities, core activities and closing activities.

Observation stage is done by the observer by recording the important findings during the learning process either by teachers or students in the classroom. Observer takes a sitting position in the back row to the right. The sitting position of the observer is very strategic so that the activities in the learning process can be recorded properly. Researchers and observers discussed after the learning process to discuss weaknesses and advantages during the learning process that will be used as a basis for reflection and improvement in subsequent learning.

The results of observation of the learning process that has been done is as follows: (1) students still find difficulties in understanding the material; (2) the props used are still lacking; (3) there was a commotion at the time of division of the group; (4) there are still students who play alone; (5) physically students interest in learning began to appear, but mentally can not be ascertained because generally in working on their worksheet just looks clustered; and (6) students who are physically and mentally interested only a few students, especially on duty writing on the worksheet.

Reflexion stage where the researcher review and conclude the result of action that has been done based on the data that has been collected and the result of the discussion with the observer. A reportable conclusion from the implementation of the improvement of Cycle I learning that the students' learning achievement has improved although not optimal (10 students or $32 \%$ of 31 students have reached completeness of study and unfinished 21 students or $68 \%$ ). Increased interest in student learning that target researchers have not achieved, only 14 students $(45 \%)$ of 31 students who really showed a high interest in learning.

\section{Cycle II}

Implementation of research in cycle II through four stages of planning, implementation, observation, and reflection. At the planning stage, the researcher prepares the learning device based on the result of reflection on cycle I. The result of reflection shows that the teaching aids used in learning is still less so the researcher add beads props by inviting the students to make the beads themselves to be brought to the class. The beads are used by students in experimenting to calculate the sum of integers.

Implementation phase of the teacher implements what already exists in the learning scenario. The initial activity of student learning is invited to sing "If You Love Your Heart" so that the students are eager to start the learning process. In the core activities, students conduct group discussions related to the summing of integers by using props that students have. Students are invited to think and respond to each other about the results of discussions from other groups. The final activity, the teacher provides feedback on the material that has been discussed. In addition, teachers provide an evaluation of the students to measure the success of the learning process that has been done.

Observation stage, researchers are assisted by the observer to observe during the learning process takes place. Observer notes on the inertrumen that researchers have provided. Observations focused on teacher teaching behavior, student learning behavior, and interaction between teachers and students. The observer gives a check mark $(\sqrt{ })$ on the Good, Fair or Less columns for each student, based on aspects of group performance, enthusiastic in seeking information, performance in discussion and responds to teacher questions, and provides written notes/ comments on learning improvement activities Which is written under the observation sheet.

Stage reflection, researchers discussed with the observer about the observations during the learning process. The results of reflection are as follows: (1) only two groups whose members are actively involved in the discussion, the other two groups only the chairman and secretary are working; (2) as the discussion period ends, two groups have not completed their student worksheet still there are some questions that have not been filled; (3) when group work there are still students playing games; (4) two of the four groups are still confused with the material presented by the teacher; and (5) student formative test results show $12(39 \%)$ of 31 students whose value is still below KKM. 


\section{Cycle III}

Implementation cycle III is divided into four stages of planning, implementation, observation, and reflection. Planning phase is done based on the result of reflection on cycle II. This stage of the researcher prepares instructional devices according to the input observer based on the weaknesses that occur in the implementation of cycle II. Researchers prepare learning scenarios along with the tools such as props, teaching materials, worksheets, teacher and student observation sheets, and questionnaires.

The Implementation Phase, the teacher implements what is already in the learning scenario covering the initial, core, and closing activities. Initial activity, the teacher invites students to sing the song "Let's Learn Math" with accompaniment of student's applause and gestures. The core activity, the students conduct group discussions related to the summing of integers by using props that students have. Students are invited to think and respond to each other about the results of discussions from other groups. The final activity, the teacher provides feedback on the material that has been discussed. In addition, teachers provide an evaluation of the students to measure the success of the learning process that has been done.

Observation stage, researchers are assisted by the observer to observe during the learning process takes place. The Observer notes on the important information that occurs during the learning process. Observations focused on teacher teaching behaviors, student learning behaviors, and interactions between teachers and students. The Observer gives a check mark $(\sqrt{ })$ in the Good, Fair or Less columns for each student, based on the performance aspect in the group, enthusiastic in finding information, performance in the discussion and responds to the teacher's questions, and gives written notes / comments on the observation sheet.

Stage reflection, researchers with observers conducted a discussion related to the observation. Results of analysis related to student interest in high mathematics learning is evidenced by the student interest instrument that is equal to $85 \%$ (26 students). The researchers also examined the formative test sheet of children and summarized the results, it turns out that the results of formative test work of 95\% (29 students) get the value of 80 or above or in accordance with the success indicator that the researchers specify the value of 80 .

The results of the research on cycles I, II, and III that student achievement and student interest in learning mathematics experience a significant improvement. For more details can be seen in Figure 1.1 below.

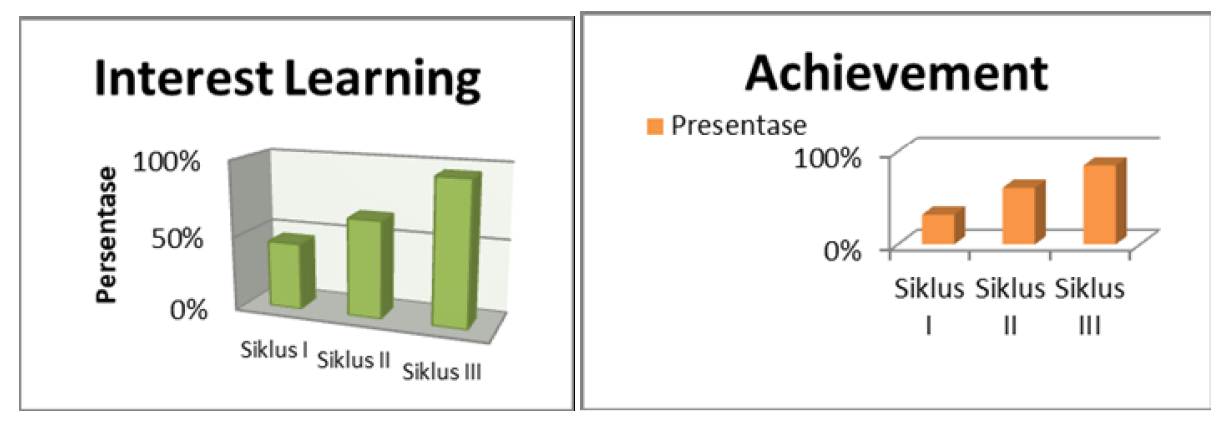

Figure 1

Increased Student Interest and Achievement

Based on Figure 1, it can be concluded that high student interest in cycle I is only $45 \%$ (14 students), in cycle II $65 \%$ (20 students), and III cycle to 95\% (29 students). On student achievement in cycle I only reached mastery of $32 \%$ or 10 students from 31 students. Cycle II completeness of student achievement rose to $61 \%$ or 19 students from 31 students. Cycle III rose to $85 \%$ or 26 students from 31 students.

The results of the research on Mathematics subjects the concept of addition of integers with PAKEM approach with the help of beads is pleasing to the students so as to make the students' interest in learning. In line with Rusman (2010) opinion states that learning is fun learning becomes the most important aspect in PAKEM approach. Laksono (2016) also revealed that students' interest in learning can be built through fun.

Hardwinoto and Setiabudhi (2006) mentions that the interest of students, especially in math lessons will increase if students can understand and solve math problems degan easily. Students who are able to get the best score in Mathematical repetition, the achievements obtained directly will give a sense of pride. The pride is formed interest to achieve better value, then the desire will spur the birth of interest in learning.

Sudrajat states that PAKEM Approach as an active, creative, effective, and joyful learning approach (Derap Guru Magazine, 2009). Active is meant that in the learning process the teacher must create in such a way that the student actively ask, question, and put forward the idea. The active role of the student is crucial in the formation of a creative generation, capable of producing something for the benefit of himself and others.

Creative is also intended for teachers to create diverse learning activities that meet the various levels of student ability. Effective intended to take advantage of time to learn so that learning objectives can be achieved. Fun is a fun learning environment so that the students focus their full attention on learning so that the time of their attention is high. Mathematics Learning 
using PAKEM Approach to be more effectively supported through instructional media.

The media functions according to Usman and Asnawir (2002) have practical values as follows: (1) media can overcome various limitations of experience owned; (2) media can overcome the classroom; (3) media allows for direct interaction between students and the environment; (4) media produces uniform observations; (5) media can embed the basic concepts that are true, concrete, and realistic; (6) media can evoke new desires and interests; (7) media can generate motivation and stimulate students to learn; and (8) media can provide an integral experience from something concrete to something abstract.

The Beads is a tool for students to understand the concept of learning Mathematics. The bead props approach uses a set concept. The concept of the set as we know that in the set, we can combine or separate the two sets in which the members are beads-shaped. The use of beads in learning Mathematics in accordance with the characteristics of elementary students. Sumantri (2014) mentions that the characteristics of elementary students are happy to play, love to move, enjoy learning in groups, and enjoy feeling or doing / demonstrating something directly.

Mathematics learning in accordance with the characteristics of elementary students will increase student interest and achievement in learning. Holland quoted by Djaali (2007) says that interest is a high tendency towards something. Interests have a very close relationship with encouragement in a person that raises a person's desire to participate in what he or she is interested in. Students who are interested will feel happy so will pay attention to an object that is manifested with high student curiosity towards the object.

Growing student interest in learning is very important to be done by teachers so that students grow a sense of love towards something where students will do such actions to learn Math. Marsun and Martaniah argue that learning achievement is the result of learning activities, namely the extent to which learners mastered the subject matter taught, followed by the emergence of a sense of satisfaction that he has done something well (Tjundjing, 2001). This means that the achievement of learning can only be known if it has been done assessment of student learning outcomes.

\section{CONCLUSION AND SUGGESTION}

The use of beads props in the PAKEM approach is very helpful for students in increasing the interest and achievement of Primary School students especially in Mathematics subjects. Students' interest in learning can have implications on student achievement. Students have an interest in learning when classroom learning is fun. Better as a teacher always innovate to produce a fun learning process for students.

\section{REFERENCES}

[1] Akhmad, S. 2009. Derap Guru Central Java. Semarang: PGRI Publishing Foundation of Central Java Province.
[2] Augusta, R. R. 2011. Guidelines for Formulation of Proposals and Classroom Action Research Reports. Purwokerto: Open University.

[3] Djaali, and Muljono, P. 2007. Measurements in the Education Sector. Jakarta: Grasindo.

[4] Government Regulation No. 19 Year 2005 about National Education Standards. Retrieved December 12, 2016, from sipma.ui.ac.id/files/dokumen/U_SNP.../PP0322013_SN P.pdf downloaded.

[5] Hardwinoto, \& Setiabudhi. 2006. Superior Child Berotak Prima. Jakarta: Gramedia.

[6] Laksono, S. Y. 2016. Relationship of Student Learning Interest to Student Mathematics Learning Achievement in Cooperative Learning STAD Type Using Comic. Journal of Mathematics and Science Education, 1(2). Retrieved December 20, 2016, from ejournal.ikippgrimadiun.ac.idindex.php/JEMS/article/do wnload/143/121.

[7] Muhsetyo, G. 2008. Elementary Mathematics Learning. Jakarta: Open University.

[8] Rusman. 2010. Learning Models. Bandung: Mulia Mandiri Press.

[9] Tjundjing, S. 2001. Relationship between IQ, EQ, and QA with Student Achievement in High School Students. Anima Journal, 17(1), 71-78.

[10] Uno, H. B. 2010. Learning Model Creates Creative and Effective Teaching Process. Jakarta: Earth Literacy.

[11] Usman, M. B., and Asnawir. 2002. Instructional Media. Jakarta: Ciputat Press. 